\title{
An Ionotropic GABA Receptor with Novel Pharmacology at Bullfrog Cone Photoreceptor Terminals
}

\author{
Jian Liu ${ }^{a}$ b Geng-Lin Li ${ }^{a, b}$ Xiong-Li Yang ${ }^{a}$

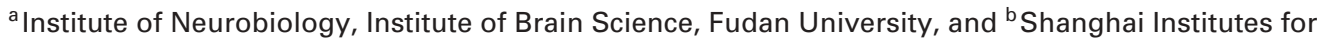 \\ Biological Sciences, and Graduate School, Chinese Academy of Sciences, Shanghai, PR China
}

\section{Key Words}

Bicuculline - Cone photoreceptor - Chloride channel · Ionotropic GABA receptor $\cdot$ Retina $\cdot$ Bullfrog

\begin{abstract}
Characteristics of ionotropic $\gamma$-aminobutyric acid (GABA) receptors at bullfrog cone terminals were studied by patch clamp techniques in isolated cell and retinal slice preparations. GABA-induced inward currents from isolated cones reversed in polarity at a potential, very close to the chloride equilibrium potential, and they were completely suppressed by picrotoxin. Unexpectedly, the GABA current was dose-dependently potentiated by the well-known $G_{A B A_{A}}$ receptor antagonist bicuculline $(B I C)$, but was suppressed by gabazine, another $G A B A_{A}$ antagonist, and imidazole-4-acetic acid (I4AA), a GABA ${ }_{C}$ receptor antagonist. Similarly, currents induced by both $\mathrm{GABA}_{A}$ agonist muscimol and $\mathrm{GABA}_{C}$ agonist cis-4-aminocrotonic acid (CACA) were also potentiated by BIC. Furthermore, currents induced from cones by GABA and kainate-caused depolarization of horizontal cells in retinal slice preparations were both potentiated by BIC. All these results suggest that the ionotropic GABA receptor at the bullfrog cone terminal exhibits novel pharmacology, distinct from both traditional $G_{A B A}$ and $G A B A_{C}$ receptors.
\end{abstract}

Copyright (C) 2006 S. Karger AG, Basel

\section{KARGER}

Fax +4161306 1234 E-Mail karger@karger.ch www.karger.com (c) 2006 S. Karger AG, Basel 1424-862X/06/0151-0013\$23.50/0

Accessible online at: www.karger.com/nsg

\section{Introduction}

As a principal inhibitory neurotransmitter in the central nervous system (CNS), including the retina, GABA acts at ionotropic $\mathrm{GABA}_{\mathrm{A}}$ and $\mathrm{GABA}_{\mathrm{C}}$ receptors and metabotropic $\mathrm{GABA}_{\mathrm{B}}$ receptor [1-3]. $\mathrm{GABA}_{\mathrm{B}}$ receptors belong to the superfamily of G-protein-coupled receptors and they activate the second-messenger pathways, phospholipase $C$ and adenylate cyclase [4, 5]. While ionotropic $\mathrm{GABA}_{\mathrm{A}}$ and $\mathrm{GABA}_{\mathrm{C}}$ receptors are both directly coupled with chloride channels, they are structurally, pharmacologically and physiologically different. $\mathrm{GABA}_{\mathrm{A}}$ receptors are hetero-oligomeric, consisting of several subunits (e.g. $\alpha, \beta, \gamma, \delta, \theta)$, and they are specifically blocked by bicuculline (BIC) and have modulatory binding sites for barbiturates, benzodiazepines, ethanol and neurosteroids [2, 6]. On the other hand, $\mathrm{GABA}_{\mathrm{C}}$ receptors are homo-oligomeric in most cases, made up of either $\rho_{1}$ or $\rho_{2}$ subunits. The $\mathrm{GABA}_{\mathrm{C}}$ receptor, like the $\mathrm{GABA}_{\mathrm{A}}$ receptor, can be blocked by picrotoxin, a nonselective chloride channel blocker, and the potent antagonist I4AA [7, 8], but is insensitive to $\mathrm{BIC}$. In addition, the $\mathrm{GABA}_{\mathrm{C}}$ receptor is more sensitive to GABA than the $\mathrm{GABA}_{\mathrm{A}}$ receptor [9-12], and currents mediated by these two types of GABA receptors are also different in kinetics [13-16].

Localization of GABA receptors in photoreceptors has been morphologically revealed in several species [17-24].

Dr. Xiong-Li Yang

Institute of Neurobiology, Fudan University

220 Handan Road

Shanghai 200433 (PR China)

Tel. +86 215552 2874, Fax +86 215552 2876, E-Mail xlyang@fudan.edu.cn 
Furthermore, ionotropic GABA receptor-mediated responses have been recorded from cones of turtle, porcine and mouse [14, 25, 26]. GABA receptors expressed in cones are thought to be involved in negative feedback from horizontal cells to these photoreceptors [26, 27], which may contribute to the receptive field surround response of bipolar cells. We recently reported that functional $\mathrm{GABA}_{\mathrm{B}}$ receptors are expressed at the bullfrog cone terminal [28], which may provide a negative feedback mechanism for regulating signal transmission between cones and second-order neurons by modifying the amount of glutamate released from the cones. In the present work, we further studied ionotropic GABA receptors at bullfrog cone terminals in both isolated cell and retinal slice preparations using patch clamp techniques and found that these receptors possessed novel pharmacology. In particular, current responses of these receptors to GABA application were potentiated by BIC, but suppressed by picrotoxin.

\section{Materials and Methods}

\section{Isolated Cell and Retinal Slice Preparations}

Adult bullfrogs (Rana catesbeiana) were used in the present work. All efforts were made to minimize animal pain and discomfort in accordance with the NIH guidelines for animal experimentation and to reduce the number of animals used.

Isolated cone photoreceptors were conventionally made using a procedure described previously in detail [29] with minor modifications. The retina was isolated and cut into 8-12 pieces, and these retinal pieces were incubated in normal Ringer's with $75 \mathrm{U} /$ $\mathrm{ml}$ papain (Washington Biochemical Corp., Freehold, N.J., USA) and $1 \mathrm{mg} / \mathrm{ml}$ cysteine (Sigma, St. Louis, Mo., USA) for $30 \mathrm{~min}$ at $25^{\circ} \mathrm{C}$. The papain-treated pieces were stored at $4^{\circ} \mathrm{C}$ for up to $2 \mathrm{~h}$. Retinal cells were freshly dissociated from one stored piece by mechanical trituration just before each experiment. The cell suspension was placed on a Petri dish mounted on the stage of a phasecontrast microscope (IX70, Olympus Optical, Tokyo, Japan). Cones with characteristic morphology were picked up for whole cell recording. Identification of cones us described in 'Results'. For comparison purposes, current responses to GABA application were also recorded from amacrine-like cells. These cells had a small $(30-50 \mu \mathrm{m})$ pyriform-shaped soma and were quite similar in morphology to the monostratified amacrine cells described in tiger salamanders [30].

Retinal slices were prepared following the procedures reported previously $[8,28]$. In brief, the dark-adapted retina was isolated and then cut into $150-\mu \mathrm{m}$-thick slices in Ringer's using a manual cutter (ST-20, Narishige, Tokyo, Japan). The slices were then transferred into a recording chamber with the cut side up and they were held mechanically in place by a grid of parallel nylon strings glued onto a U-shape frame of platinum wire. All these procedures were performed under dim red illumination. The glass-bottomed recording chamber with a volume of approximately $1.0 \mathrm{ml}$ was continuously perfused with the oxygen-bubbled extracellular solution, which was fed in and out of the chamber through inlets by a peristaltic pump (Minipulse 3, Gilson Medical Electronics, Viuiers Le Bel, France) at a rate of $3-5 \mathrm{ml} / \mathrm{min}$.

\section{Solutions and Drug Application}

For experiments with isolated cones, Ringer's with an osmolality of $250 \mathrm{mosm} / \mathrm{kg} \mathrm{H}_{2} \mathrm{O}$ consisted of (in $\mathrm{mM}$ ) $120 \mathrm{NaCl}, 2.0 \mathrm{KCl}$, $2.0 \mathrm{CaCl}_{2}, 1.0 \mathrm{MgCl}_{2}, 10$ 4-(2-hydroxyethyl)piperazine-1-ethanesulfonic acid (HEPES) and 10 glucose, $\mathrm{pH}$ adjusted to 7.4 with $\mathrm{NaOH}$. All drug-containing solutions were delivered using a stepper motor-based rapid solution changer RSC-100 (Bio-Logic Science Instruments, Mundelein, France), as described in detail previously [31]. The recorded cells were completely bathed in the solution by lifting them from the dish bottom. The solution exchange could be completed in a few milliseconds.

For experiments with retinal slice preparations, Ringer's with an osmolality of $250 \mathrm{mosm} / \mathrm{kg} \mathrm{H}_{2} \mathrm{O}$ consisted of (in $\mathrm{m} M$ ) $100 \mathrm{NaCl}$, $25 \mathrm{NaHCO}_{3}, 2.5 \mathrm{KCl}, 1.6 \mathrm{MgCl}_{2}, 2.0 \mathrm{CaCl}_{2}$, and 10 glucose, $\mathrm{pH}$ adjusted to 7.4 by bubbling with $95 \% \mathrm{O}_{2}$ and $5 \% \mathrm{CO}_{2}$. GABA containing Ringer's was pressure ejected by nitrogen gas via a Picospritzer II (General Valve, Houston, Tex., USA), which was triggered by the Pulse software (PulseFit 8.65, HEKA, Lambrecht/ Pfalz, Germany), and focally applied at the cone photoreceptor terminal using a pneumatic puff pipette with a motor-driven micromanipulator (MP-285, Sutter, Novato, Calif., USA). The position of the pipette with a tip size of 3-5 $\mu \mathrm{m}$ in diameter was adjusted to obtain consistent drug-induced effects. The pressure in the puff pipette was optimized for the consistency of drug delivery, and when no pressure was applied to the pipette, a small amount of the bath medium was continuously sucked into the pipette by capillary attraction, thus preventing the drug solution from leaking out. The actual concentration of GABA, muscimol and CACA at the cell membrane was surely much lower because of bulk flow, diffusion and potent uptake systems in the retina. Drugs other than GABA were applied by administrating drug-containing Ringer's into the bath medium through another inlet.

To record chloride currents, the intracellular solution for wholecell voltage clamp in both isolated cell and retinal slice preparations consisted of (in $\mathrm{mM}$ ) $128 \mathrm{CsCl}, 2.0 \mathrm{MgCl}_{2}, 1.0 \mathrm{CaCl}_{2}, 10$ ethylene glycol-bis(2-aminoethylether)-N,N, $\mathrm{N}^{\prime}, \mathrm{N}^{\prime}$-tetra-aceticacid(EGTA), 10 HEPES, with an osmolality of $240 \mathrm{mosm} / \mathrm{kg} \mathrm{H}_{2} \mathrm{O}$.

All chemicals were purchased from Sigma Chemicals and freshly dissolved in Ringer's when used.

\section{Whole-Cell Voltage Clamp Recording}

The recording chamber containing retinal slices was placed on a fixed-stage microscope (Zeiss, Axioskop 2 FS Mot, Jena, Germany), which was equipped with infrared differential interference contrast (DIC) optics. A water-immersion objective with a working distance of $1.4 \mathrm{~mm}$ was used (Zeiss, 63W, 0.95NA). During the experiments, the cells were imaged by an infrared video camera (C2400-79, Hamamatsu, Shizuoka, Japan) and visualized on a TV monitor (Panasonic, Osaka, Japan).

Recording patch electrodes were pulled from borosilicate glass (BF150-86-10, Sutter) with a multi-stage horizontal puller (P-97, Sutter). For recording current responses from isolated cones in the voltage clamp mode, patch pipettes with a tip diameter of about $2 \mu \mathrm{m}$, resistance of 5-7 M $\Omega$ when filled with the intracellular solution, were used. The resistance of the electrodes used in retinal slice preparations was $8-10 \mathrm{M} \Omega$. The recording pipette was connected 
to a patch amplifier (EPC9/2, HEKA) and the liquid junction potential was calculated, which was $3.96 \mathrm{mV}$ for experiments with isolated cells and $2.84 \mathrm{mV}$ for those with slice preparations $\left(25^{\circ} \mathrm{C}\right)$, and it was auto-compensated by the software (Pulse 8.65, HEKA). Eighty percent of serial resistance of the recording electrode was compensated and it remained unchanged during the experiments. Voltage clamp data were acquired at a sample rate of $20 \mathrm{kHz}$, filtered at $2 \mathrm{kHz}$ and they were stored in computer hard disk for further analysis.

\section{Data Processing}

Data analysis was done using PulseFit 8.65 (HEKA), OriginPro 7.0 (OriginLab Corp., Northampton, Mass., USA) and Igor 4.09A (WaveMetrics, Lake Oswego, Oreg., USA). The reversal potential for the GABA receptor was determined by fitting the steady-state current response recorded when the cells were clamped at various voltage levels with a linear function:

$$
I=A \times\left(V-E_{r e v}\right)
$$

where I is the steady-state current at a certain voltage level, which is determined by averaging sampled data points during $100 \mathrm{~ms}$ prior to the cessation of a voltage step, $\mathrm{V}$ is the clamping voltage, $\mathrm{A}$ is a constant, and $\mathrm{E}_{\mathrm{rev}}$ is the reversal potential.

Dose-response data of agonists or antagonists were fitted to the following Hill equations using a nonlinear least-squares method:

For activation:

$$
\frac{I}{I_{\max }}=\frac{1}{1+\left(\frac{E C_{50}}{[\text { agonist }]}\right)^{n}}
$$

For inhibition:

$$
\frac{I}{I_{\max }}=\frac{1}{1+\left(\frac{[\text { antagonist }]}{I C_{50}}\right)^{n}}
$$

where $\mathrm{I}_{\max }$ is the steady-state response at a saturating concentration of an agonist or antagonist, which is measured by averaging sampled data points during $100 \mathrm{~ms}$ before the cessation of a 1-second application; $\mathrm{EC}_{50}$ is the concentration of the ligand producing half-maximal response; $\mathrm{IC}_{50}$ is the concentration of the antagonist producing half-maximal inhibition; $\mathrm{n}$ is the Hill coefficient. Dose-dependent potentiation of GABA (or agonist-)-induced currents by BIC were also fitted to equation (2) with appropriate modification.

\section{Results}

\section{Characterization of Ionotropic GABA Receptors at} Isolated Bullfrog Cone Terminals

Isolated bullfrog cones are easily identified by characteristic morphology typical of amphibian cones. Figure 1a shows an isolated cone with the axon terminal (arrow) under DIC microscopy. Under phase-contrast microscopy, a bright oil-droplet was clearly seen in the inner segment, indicating that the cell was a single cone or the principal member of a double cone. Cones without oildroplets but with morphology typical of these photoreceptors may be the accessory member of double cones. These cells were also picked up for patch clamp experiments. There was no qualitative difference in regard to the characteristics of GABA-induced currents studied between these two cell types. In the present work, only data obtained in cones with oil-droplets were pooled and analyzed. Moreover, no GABA-induced current could be recorded in cones which lost axon terminals during mechanical trituration, suggesting the localization of GABA receptor on the terminals.

Figure $1 \mathrm{~b}$ shows the current responses of an isolated cone induced by GABA of increasing concentrations when clamped at $-60 \mathrm{mV}$. GABA of a concentration as low as $0.1 \mu M$ could induce a sustained inward current of $30 \mathrm{pA}$ with slow activation. As GABA concentration was increased, the rise time of the current became faster, which was accompanied by a steady increase in size, but the deactivation was still rather slow. The current was saturated in size to $100 \mu M$ GABA. It was noteworthy that all these current responses were sustained and did not show desensitization. Figure 1c shows the average dose-response relationship of the GABA currents recorded from 36 cones. For constructing this relationship, the current responses of each cell to GABA of different concentrations were normalized by its response to $100 \mu M$ GABA, and the normalized data were then averaged and plotted as percentages of the maximum response. The experimental data were well fitted by the curve described with equation (2). The $\mathrm{EC}_{50}$ for GABA was 0.68 $\pm 0.01 \mu M$ (mean $\pm \mathrm{SEM})$, which is clearly smaller than that of either $\mathrm{GABA}_{\mathrm{A}}$ or $\mathrm{GABA}_{\mathrm{C}}$ receptors reported previously $[12,32,33]$, and the Hill coefficient was close to $1(0.82 \pm 0.01)$.

Figure 1d shows the current-voltage (I-V) relationship of the GABA currents recorded from an isolated cone at different holding potentials. According to equation (1), the $\mathrm{E}_{\text {rev }}$ for these currents was $2.5 \mathrm{mV}$. The average $\mathrm{E}_{\text {rev }}$ of 5 cones tested was $2.4 \pm 0.8 \mathrm{mV}$, which is very close to the chloride equilibrium potential $\left(\mathrm{E}_{\mathrm{Cl}}\right)\left(1.2 \mathrm{mV}, 25^{\circ} \mathrm{C}\right)$ under our experimental conditions. When the chloride concentration in the intracellular solution was changed, the $\mathrm{E}_{\mathrm{rev}}$ was accordingly shifted (data not shown). Moreover, the GABA currents were completely blocked by coapplication of $500 \mu M$ picrotoxin (fig. $1 \mathrm{~d}$, inset). All these results indicated that the GABA currents recorded from the bullfrog cones were mediated through chloride channels. 


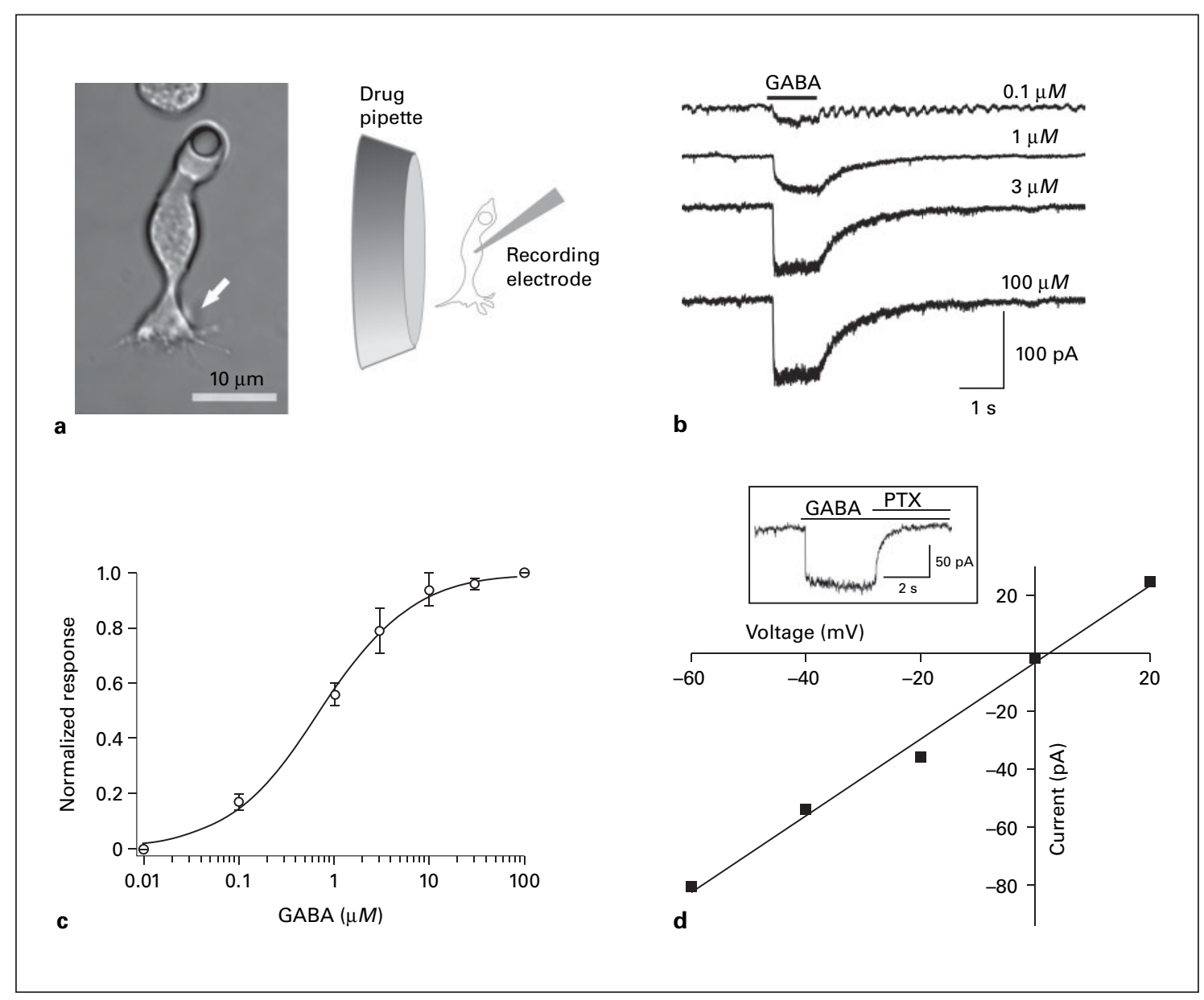

Fig. 1. GABA-induced responses from isolated bullfrog cones. a DIC microphotograph of an isolated cone with the axon terminal (arrow) at a high magnification $(\times 400)$. An oil droplet could be clearly seen in the inner segment. The outer segment of the cell was lost during dissociation. The schematic diagram in the right shows how a drug pipette and a recording electrode were positioned. b Current responses of an isolated cone to GABA of different concentrations delivered by a rapid solution changer. The cell was voltage clamped at $-60 \mathrm{mV}$. The currents were rather sustained with slow deactivation. GABA of $100 \mu M$ induced a maximum response. c Dose-response relationship of GABA currents of bullfrog cones. Steady-state currents of each cone in response to various concentrations of GABA, when voltage clamped at $-60 \mathrm{mV}$, were normalized to the response of that cell to $100 \mu M$ GABA and then averaged.
The averaged data were fitted by the Hill equation (Eq. 2). Data for each point were pooled from 6 cones. The $\mathrm{EC}_{50}$ was $0.68 \pm$ $0.01 \mu M$ (mean \pm SEM), and the Hill coefficient was $0.82 \pm 0.01$ ( $n=36)$. d Current-voltage (I-V) curve for the GABA currents recorded in a representative cone. The averaged steady-state GABA currents (filled squares) obtained, when clamped at various voltage levels (from -60 to $+20 \mathrm{mV}$ at $20-\mathrm{mV}$ increments), were well fitted by a linear function (solid line). The reversal potential $\left(\mathrm{E}_{\mathrm{rev}}\right)$ for the GABA currents obtained from this cone was $2.5 \mathrm{mV}$, very close to the chloride equilibrium potential $\left(\mathrm{E}_{\mathrm{Cl}}\right)$ under our experimental condition $\left(1.2 \mathrm{mV}, 25^{\circ} \mathrm{C}\right)$. The inset shows that $500 \mu M$ picrotoxin (PTX) completely suppressed the current of the cone to $100 \mu M$ GABA.

ingly, co-application of BIC did not suppress, but potentiated the GABA currents. Figure 2 a shows how the response of an isolated cone to $100 \mu M$ GABA was dosedependently potentiated by BIC of increasing concentrations. For this experiment, BIC continuously perfused the cell and responses to $100 \mu M$ GABA were recorded in the presence of BIC. BIC alone did not induce 


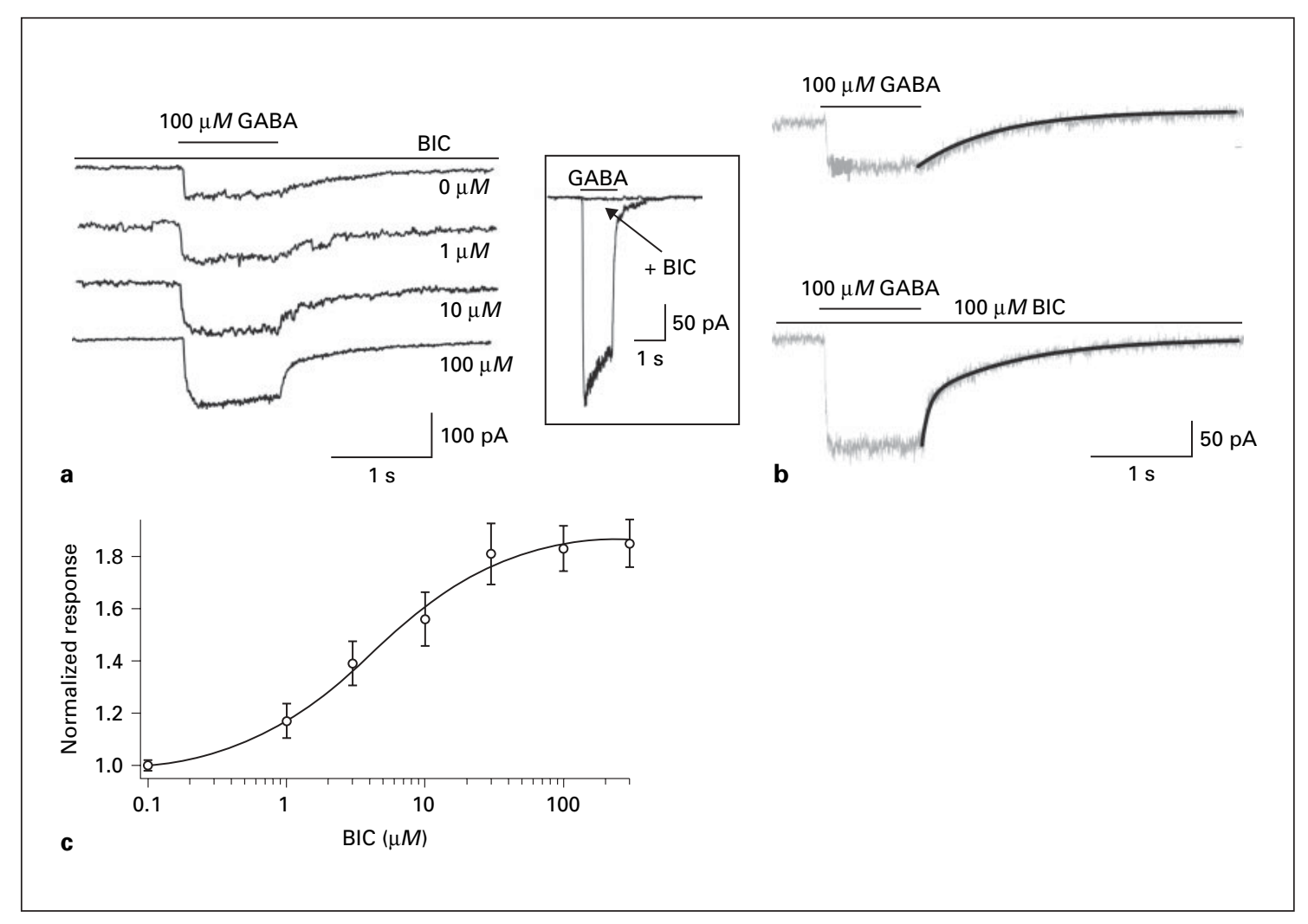

Fig. 2. GABA currents of cones are potentiated by bicuculline (BIC). a Currents induced by $100 \mu M$ GABA from an isolated cone were potentiated by BIC in a dose-dependent manner. The BIC concentration is indicated on the right of each trace. The uppermost trace shows the current response induced by $100 \mu M$ GABA in the absence of BIC. BIC applied alone did not induce any current, and the BIC-potentiated currents were all sustained. Note that a fast deactivation component appeared, in addition to the slow component, in the responses to $100 \mu M$ GABA obtained in the presence of BIC of 10 and $100 \mu M$. The inset shows that GABA $(100 \mu M)$ induced current from an isolated amacrine-like cell dissociated from the same retina was completely blocked by $100 \mu M$ BIC (+BIC). In contrast to the current responses of the cone, the GABA current of the amacrine-like cell showed significant desensitization. b Change in GABA response deactivation in the presence of BIC. Upper panel: The response of an isolated cone to $100 \mu M$ GABA (grey trace) in the absence of BIC. The deactivation course was well fitted by a single exponential function (dark curve) with a time constant of $644.0 \mathrm{~ms}$. Lower panel: The response of the same cell to $100 \mu M$ GABA in the presence of $100 \mu M$ BIC (grey trace). A double-exponential function (dark curve) was needed to fit the deactivation course of the BIC-potentiated GABA current, with two time constants of 68.9 and $825.0 \mathrm{~ms}$, respectively, for the fast and slow components. c Dose-dependent potentiation of currents of isolated cones to $100 \mu M$ GABA caused by BIC. All responses from each cone were compared to the response of that cell to $100 \mu M$ GABA recorded in the absence of BIC (control) and represented as folds of control. Data determined from different cones in the presence of BIC of various concentrations were then averaged. The averaged data points were fitted by modified equation (2). The $\mathrm{EC}_{50}$ for $\mathrm{BIC}$, causing a half maximum potentiation of GABA currents, was 4.0 $\pm 0.2 \mu M$, and the Hill coefficient was $0.92 \pm 0.04(\mathrm{n}=36)$. any discernable current. The GABA response, however, was increased from 70.9 to $89.7 \mathrm{pA}$ in the presence of $1 \mu M$ BIC. When BIC concentration was increased to $10 \mu M$, the response was further increased in size to $118.5 \mathrm{pA}$. With a further increase of BIC concentration to $100 \mu M$, a still larger $(143.1 \mathrm{pA})$ response could be obtained. The potentiation extent of the GABA response obtained at $300 \mu M$ BIC was not much different from that obtained at $100 \mu M \mathrm{BIC}$ (data not shown). It is note- worthy in figure $2 \mathrm{a}$ that a new deactivation component with faster kinetics appeared in the BIC potentiated responses, in addition to the slow deactivation component. As shown in the upper panel of figure $2 b$, the deactivation course of the response to $100 \mu M$ GABA recorded from the cone in normal Ringer's could be well fitted by a single exponential function with a time constant of $644.0 \mathrm{~ms}$. The average time constant based on the data pooled from 18 cells was $721.6 \pm 31.3 \mathrm{~ms}$. Deactivation of the re- 


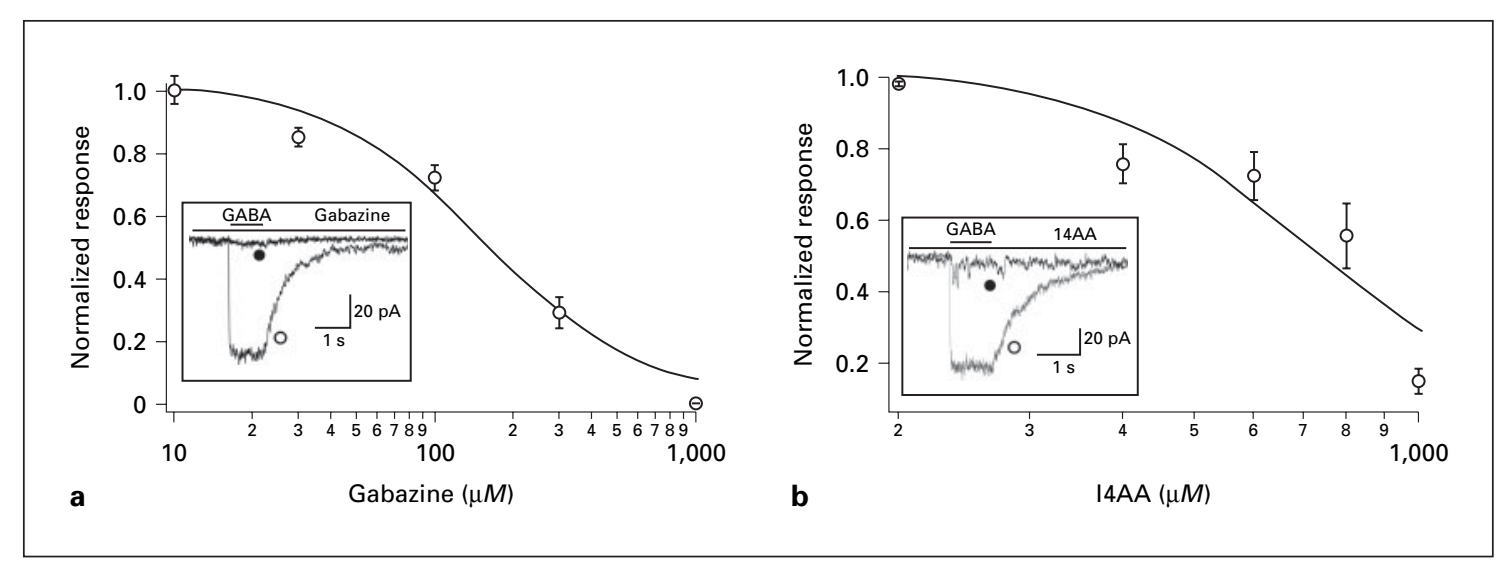

Fig. 3. Both gabazine (SR-95531) and I4AA suppress GABA currents of isolated cones in a dose-dependent manner. a Dose-dependent suppression of GABA $(100 \mu M)$ currents of isolated cones by gabazine. Data from different cones were averaged after all responses from each cone were normalized to the response of that cell to $100 \mu M$ GABA in the absence of gabazine. The averaged data points were fitted by equation (3). The $\mathrm{IC}_{50}$ of gabazine was 155.0 $\pm 8.3 \mu M$, and the Hill coefficient was $1.5 \pm 0.1(\mathrm{n}=28)$. The in- set shows that the current induced by $100 \mu M$ GABA from an isolated cone (open circle) was completely suppressed by $1 \mathrm{~m} M$ gabazine (filled circle). b Dose-dependent suppression of GABA currents of isolated cones by I4AA. Data were processed as in (a). The $\mathrm{IC}_{50}$ for $\mathrm{I} 4 \mathrm{AA}$ was $718.5 \pm 34.6 \mu M$, and the Hill coefficient was $3.0 \pm 0.7(\mathrm{n}=20)$. The inset shows that the current induced by $100 \mu M$ GABA from an isolated cone (open circle) was almost completely suppressed by $1 \mathrm{~m} M$ I4AA (filled circle). sponse of the same cell recorded in the presence of $100 \mu M$ BIC, on the other hand, should be fitted by a double exponential function with two time constants: one was $68.9 \mathrm{~ms}$ for the fast component and other was $825.0 \mathrm{~ms}$ for the slow component (lower panel). The average time constants $(\mathrm{n}=18)$ were $90.7 \pm 7.4 \mathrm{~ms}$ and $937.8 \pm$ $56.0 \mathrm{~ms}$, respectively. For comparison purpose, we also tested the effects of BIC on GABA currents recorded from isolated bullfrog amacrine-like cells. As shown in the inset of figure $2 \mathrm{a}$, the response of this amacrine-like cell to $100 \mu M$ GABA showed desensitization and was completely suppressed by co-application of $100 \mu M$ BIC. Similar observations were obtained in all 6 amacrine-like cells tested. Figure $2 \mathrm{c}$ shows the potentiation of the response to $100 \mu M$ GABA as a function of BIC concentration. The current responses of each cell to $100 \mu M$ GABA in the presence of BIC of different concentrations were normalized by that obtained in normal Ringer's (control response). The normalized data were averaged and plotted as folds of the control response. The curve described with modified equation (2) fitted the data points well, yielding a value of $4.0 \pm 0.2 \mu M(\mathrm{n}=36)$ for BIC causing halfmaximum potentiation. The Hill coefficient was close to $1(0.92 \pm 0.04)$. It should be noted, however, that responses to GABA of lower concentrations, say $1 \mu M$, could be blocked by BIC of much higher concentrations, say $1 \mathrm{~m} M$ (data not shown).
The BIC-potentiated responses were insensitive to the $\mathrm{GABA}_{\mathrm{B}}$ receptor agonist baclofen $(100 \mu M, \mathrm{n}=4)$ or antagonist saclofen $(200 \mu M, \mathrm{n}=5)$ (data not shown). The $\mathrm{E}_{\mathrm{rev}}$ for these currents $(2.2 \pm 0.6 \mathrm{mV}, \mathrm{n}=6)$ was almost unchanged, indicating that they were also mediated through chloride channels.

It was of interest that gabazine (SR-95531), another selective $\mathrm{GABA}_{\mathrm{A}}$ receptor antagonist, did not potentiate the GABA currents of bullfrog cones, but suppressed them in a dose-dependent manner. Figure 3 a shows the effects of gabazine of increasing concentrations on current responses of cones to $100 \mu M$ GABA. The data were processed in a way similar to that for the BIC-induced potentiation. Curve fitting using equation (3) yielded an $\mathrm{IC}_{50}$ of $155.0 \pm 8.3 \mu \mathrm{M}$ and a Hill coefficient of $1.5 \pm$ $0.1(n=28)$. The GABA current was suppressed by gabazine of a concentration as low as $30 \mu M$ and almost abolished by $1 \mathrm{~m} M$ gabazine (fig. 3a, inset). Similarly, the $\mathrm{GABA}_{\mathrm{C}}$ receptor antagonist I4AA suppressed GABA currents, and the dose-suppression relationship obtained on the basis of the data pooled from 20 cones is shown in figure $3 b$. The curve described with equation (3) did not fit the data points quite well, but it was obvious that $1 \mathrm{~m} M$ I4AA almost completely suppressed the current response to $100 \mu M$ GABA (fig. $3 \mathrm{~b}$, inset). The $\mathrm{IC}_{50}$ for I4AA was $718.5 \pm 34.6 \mu M$ and the Hill coefficient was $3.0 \pm 0.7(n=20)$. 


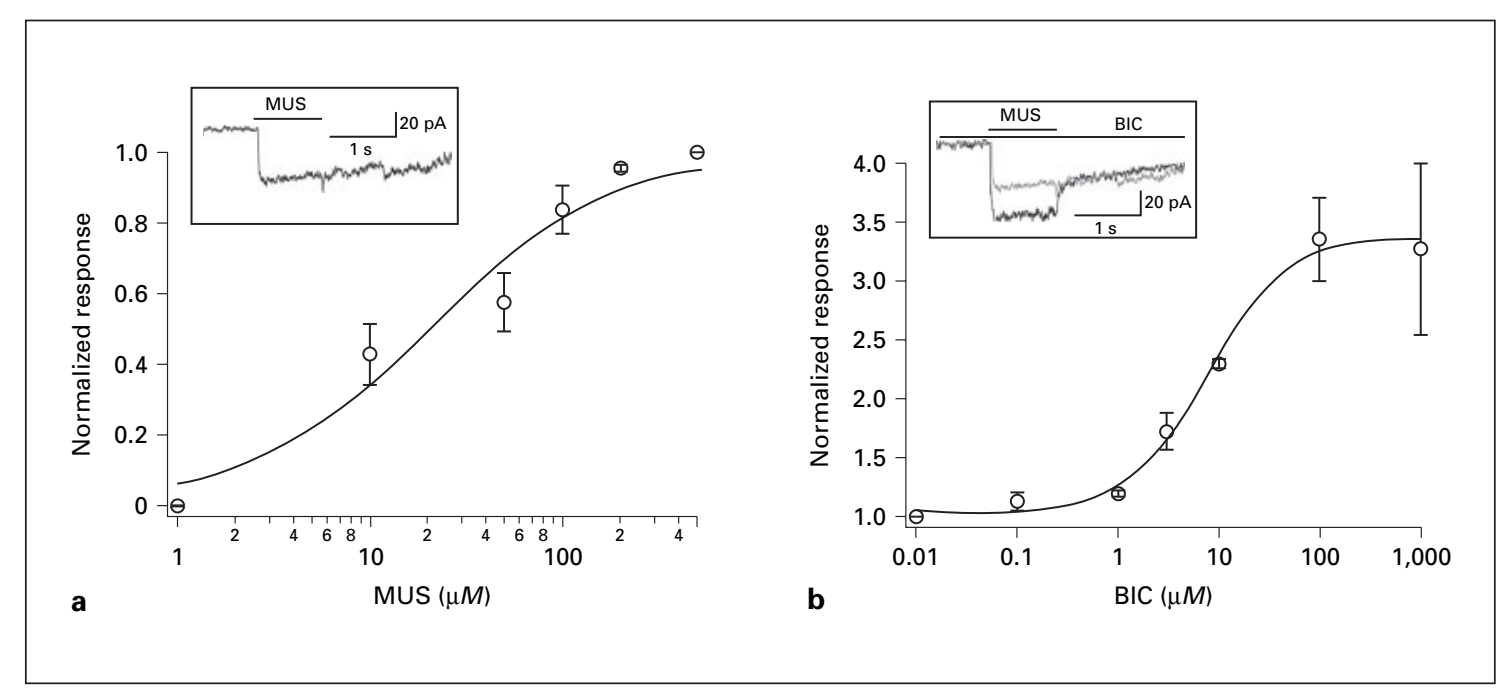

Fig. 4. Dose-response relationship of muscimol-induced currents and BIC-potentiated muscimol currents of isolated cones. a Dosedependent relationship of muscimol-induced currents of isolated cones. The data were processed as in figure 1c. All responses from each cone were normalized to the response of that cell to $500 \mu M$ muscimol. The $\mathrm{EC}_{50}$ of muscimol was $19.8 \pm 4.0 \mu M$, and the Hill coefficient was $0.92 \pm 0.08(\mathrm{n}=30)$. The inset shows the current induced by $500 \mu M$ muscimol (MUS) from an isolated cone, which was sustained with rather slow deactivation. b Dose-response relationship of BIC potentiated muscimol $(500 \mu M)$ currents of iso- lated cones. The data were processed in a similar way to that performed for the data shown in figure 2c. All responses from each cone were plotted as folds of the response induced by $500 \mu \mathrm{M}$ muscimol from that cell in the absence of $\mathrm{BIC}$. The $\mathrm{EC}_{50}$ for $\mathrm{BIC}$, producing a half maximum potentiation of muscimol currents, was 9.7 $\pm 1.2 \mu M$ and the Hill coefficient was $0.98 \pm 0.01(\mathrm{n}=36)$. The inset shows that the current response of the cell shown in the inset of (a) (grey trace) was significantly potentiated by $3 \mu M$ BIC (dark trace).
We further examined current responses of cones to the $\mathrm{GABA}_{\mathrm{A}}$ receptor agonist muscimol. Muscimol application also induced sustained inward currents, which were rather similar in waveforms to the GABA currents (cf. response in fig. 4a, inset, with those in fig. 1b). The average dose-response relationship obtained from 30 cones yielded an $\mathrm{EC}_{50}$ of $19.8 \pm 4.0 \mu \mathrm{M}$ and a Hill coefficient of $0.92 \pm 0.08$. In the inset of figure $4 \mathrm{~b}$, the response of an isolated cone to $500 \mu M$ muscimol, inducing a maximum response, was clearly potentiated in the presence of $3 \mu M$ BIC. The potentiation was dose-dependently increased and the $\mathrm{EC}_{50}$ of $\mathrm{BIC}$ for $500 \mu M$ muscimol-induced currents was $9.7 \pm 1.2 \mu M(\mathrm{n}=36)$, as yielded by the relationship shown in figure $4 \mathrm{~b}$, and the Hill coefficient $(0.98 \pm 0.01)$ was almost unchanged from that obtained in the absence of BIC. Again, BIC of much higher concentrations, say $1 \mathrm{~m} M$, could suppress the response to muscimol of a rather low concentration, say $10 \mu M$ (data not shown).

Current responses of cones to the $\mathrm{GABA}_{\mathrm{C}}$ receptor agonist CACA were also studied. CACA induced a sustained current as well, but with fast deactivation (fig. 5a, inset), which was clearly different from either GABA- or muscimol-induced current. The average dose-response relationship of the CACA current yielded an $\mathrm{EC}_{50}$ of 43.7 $\pm 5.4 \mu M$, and a Hill coefficient of $1.9 \pm 0.5(\mathrm{n}=42)$. The CACA current was potentiated by BIC of concentrations lower than $20 \mu M$, but it was suppressed at higher concentrations of BIC. The effects of BIC of low $(3 \mu M)$ and high concentrations $(200 \mu M)$ on the current response of a cone to $100 \mu M$ CACA are shown in the insets of figure $5 \mathrm{~b}$ and figure $5 \mathrm{c}$, respectively. While the CACA current was significantly potentiated by $3 \mu M \mathrm{BIC}$, it was completely suppressed by $200 \mu M$ BIC. Figure 5 b shows that the CACA current steadily increased in size with increasing concentrations of BIC in a range of $0-20 \mu M$. These data points appeared to follow a linear relation, but could not be fitted well by equation (1). A possible explanation may be that the BIC-induced suppression might have emerged, along with the potentiation, when the concentration of BIC was higher than $1 \mu M$ so that the potentiated currents obtained in a range of $1-10 \mu M$ of BIC concentration might have been suppressed to some extent. In other words, the GABA currents obtained in 


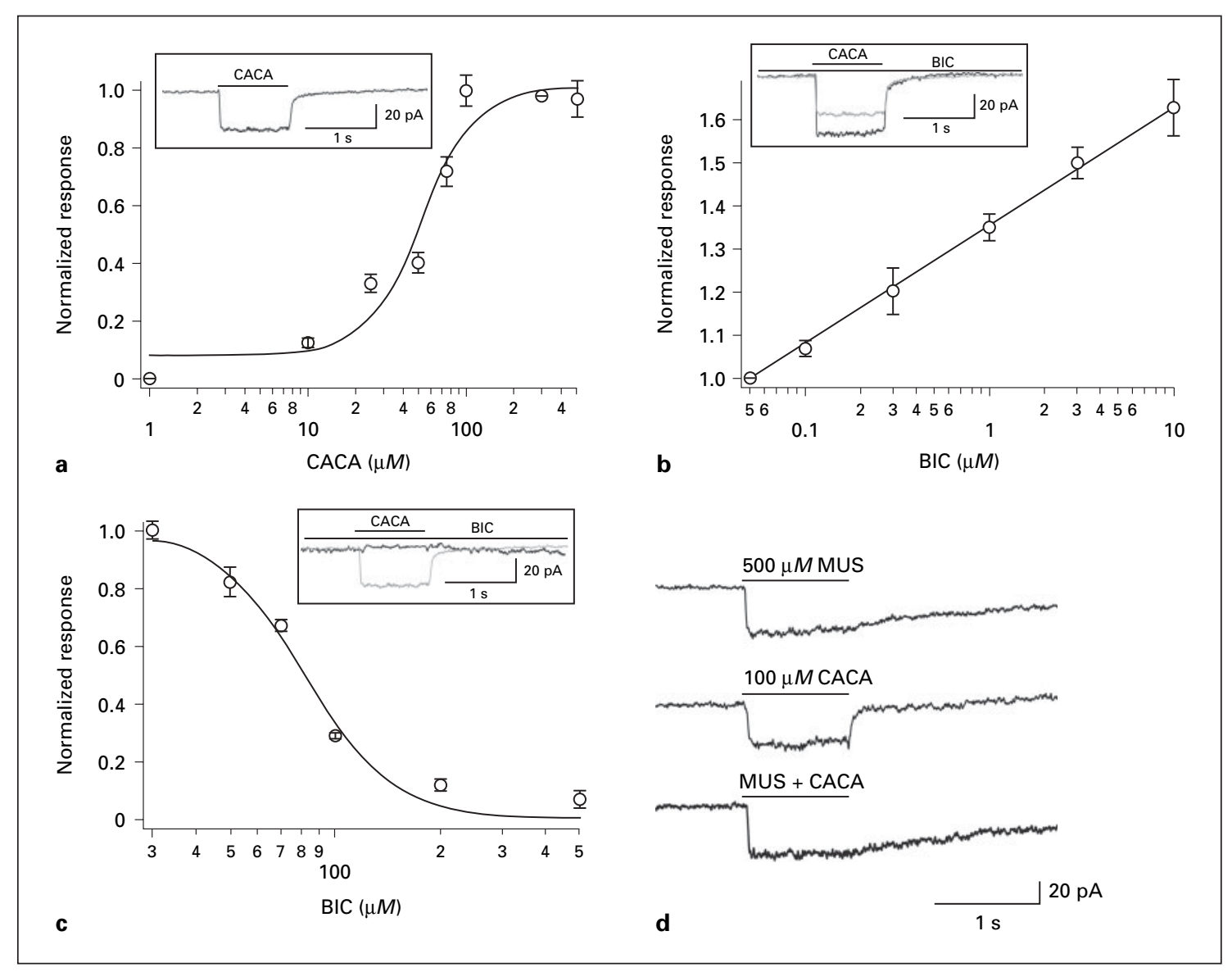

Fig. 5. Effects of BIC on CACA-induced currents of isolated cones. a Dose-dependent relationship of CACA-induced currents of isolated cones. All responses from each cone were normalized to the response of that cell to $100 \mu M$ CACA. The data points were fitted with equation (2), yielding an $\mathrm{EC}_{50}$ of $43.7 \pm 5.4 \mu M$ and a Hill coefficient of $1.9 \pm 0.5(\mathrm{n}=42)$. The inset shows that $100 \mu M$ CACA induced a sustained inward current from an isolated cone with fast activation and deactivation. b Dose-dependent potentiation of CACA currents by BIC of concentrations less than $10 \mu M$. The potentiation was almost linearly related to the logarithm of BIC concentration. The inset shows that the current of the cell to $100 \mu M$ CACA shown in (a) (grey trace) was potentiated by $3 \mu M$ BIC (dark

this range of BIC concentrations might have been larger if no such suppression existed. The amplitude of the CACA currents recorded in the presence of BIC of concentrations higher than $20 \mu M$ was plotted as a function of BIC concentration in figure $5 \mathrm{c}$. The current was dosedependently suppressed by BIC. Even though the curve described with equation (3) fitted the data points reasonably well, it might have been distorted due to the BICinduced potentiation occurring at the lower concentration range. trace). c Dose-dependent suppression of CACA currents by BIC of concentrations, higher than $30 \mu M$. The data points were fitted with equation (3). The $\mathrm{IC}_{50}$ of $\mathrm{BIC}$ was $82.0 \pm 3.0 \mu M$ and the Hill coefficient was $3.4 \pm 0.4(\mathrm{n}=30)$. The inset shows that the current of the cone to $100 \mu M$ CACA shown in the inset of (a) (grey trace) was completely suppressed by $200 \mu M$ BIC (dark trace). d Muscimol (MUS, $500 \mu M)$ and CACA $(100 \mu M)$ induced inward currents from the same isolated cone, with deactivation of different kinetics. When MUS $(500 \mu M)$ and CACA $(100 \mu M)$ were co-applied to the same cone terminal, the current induced was quite similar to the muscimol current. Similar results were obtained in 7 cones.

There was a possibility that muscimol- and CACA-induced currents may be mediated by two subtypes of ionotropic GABA receptors. To test this possibility, we compared the current response to a mixture of muscimol and CACA with those induced by muscimol or CACA alone. The upper and middle traces in figure $5 \mathrm{~d}$ are the responses of an isolated cone to $500 \mu M$ muscimol and $100 \mu M$ CACA, respectively, both of which produced maximum responses. The response induced by co-application of muscimol of $500 \mu M$ and CACA of $100 \mu M$ 


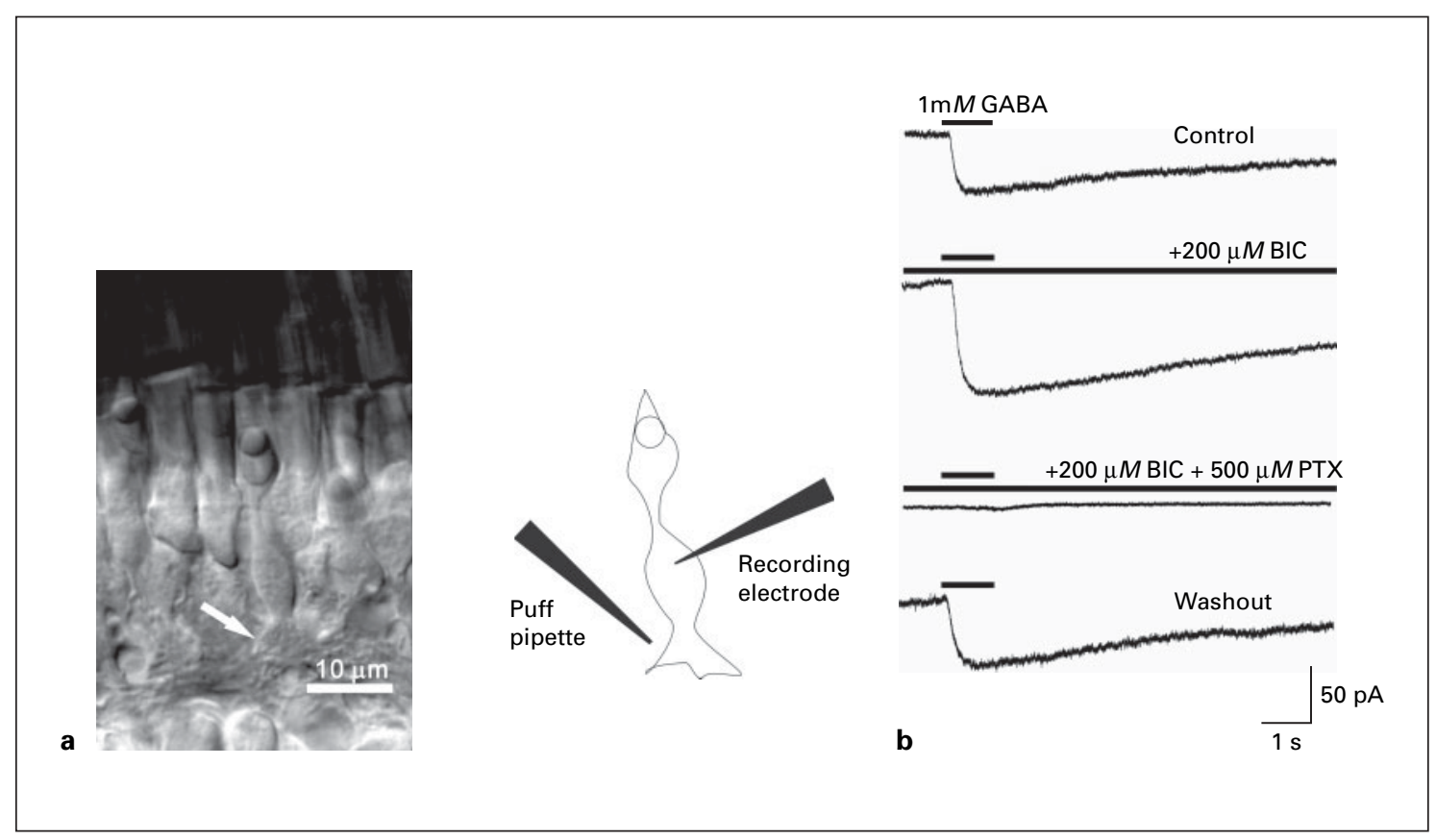

Fig. 6. Potentiation of GABA currents of cones in retinal slice preparations. a DIC microphotograph of a bullfrog retinal slice at a high-magnification $(\times 630)$, showing the distal part of the retina. Cones are easily identified by characteristic morphology and oil droplets. The terminal of a cone is indicated by arrow. The schematic diagram in the right shows how a puff pipette and a recording electrode were positioned. b GABA of $1 \mathrm{~m} M$ focally puffed to the terminal of the cone shown in (a), which was voltage clamped at
$-60 \mathrm{mV}$, induced an inward current (control). Note that activation and deactivation of the current were both much slower than those recorded from isolated cones. The GABA current was greatly potentiated in the presence of $200 \mu M \mathrm{BIC}$ added in the bath medium, but completely blocked when $500 \mu M$ picrotoxin (PTX) was added in the bath medium along with $200 \mu M$ BIC (+BIC+PTX). The GABA current returned to the control level following washout with Ringer's. (bottom trace) was obviously not the algebraic sum of the muscimol response and the CACA response, but almost identical to the muscimol response. It is reasonable to speculate that the effect caused by muscimol of the saturating concentration $(500 \mu M)$ might have occluded the action of CACA on this ionotropic GABA receptor or vice versa. Similar results were obtained in 6 other cones. These results suggest that muscimol and CACA may act at a single receptor type.

\section{Behaviors of GABA Currents at Cone Axon \\ Terminals in Retinal Slice Preparations}

To exclude the possibility that potentiation by BIC of GABA currents might be an artifact produced when cones were dissociated, we tested effects of BIC on current responses of cones recorded in retinal slice preparations while GABA was applied to their terminals. In these preparations, cones were easily identified by their localization and characteristic morphology (fig. 6a). When $1 \mathrm{~m} M$ GABA was focally puffed to the terminal of the cone, as indicated by the arrow in figure $6 \mathrm{a}$, a sustained inward current was elicited (fig. 6b, upper trace). Due to bulk flow and diffusion barrier in the retina, activation and deactivation of the current were both much slower than those obtained from isolated cones (cf. responses in fig. 1b). When the preparation was perfused with $200 \mu M$ BIC, the current response of the cone to $1 \mathrm{~m} M$ GABA was significantly potentiated (fig. $6 \mathrm{~b}$ ). In the presence of $500 \mu M$ picrotoxin, along with $200 \mu M$ BIC, $1 \mathrm{~m} M$ GABA no longer induced any discernable current.

Whole-cell recordings were further made from cones when the preparation was perfused with $40 \mu M$ kainate, which is supposed to induce the release of GABA from horizontal cells by causing large depolarization of these cells $[34,35]$. The result of such an experiment is shown in figure $7 \mathrm{a}$. As expected, perfusion with $40 \mu M$ kainate induced a sustained inward current from the cone with a 5 -second delay. Again, the current was potentiated by the addition of $200 \mu \mathrm{M}$ BIC to the perfusate but was completely suppressed by $500 \mu M$ picrotoxin. We further de- 


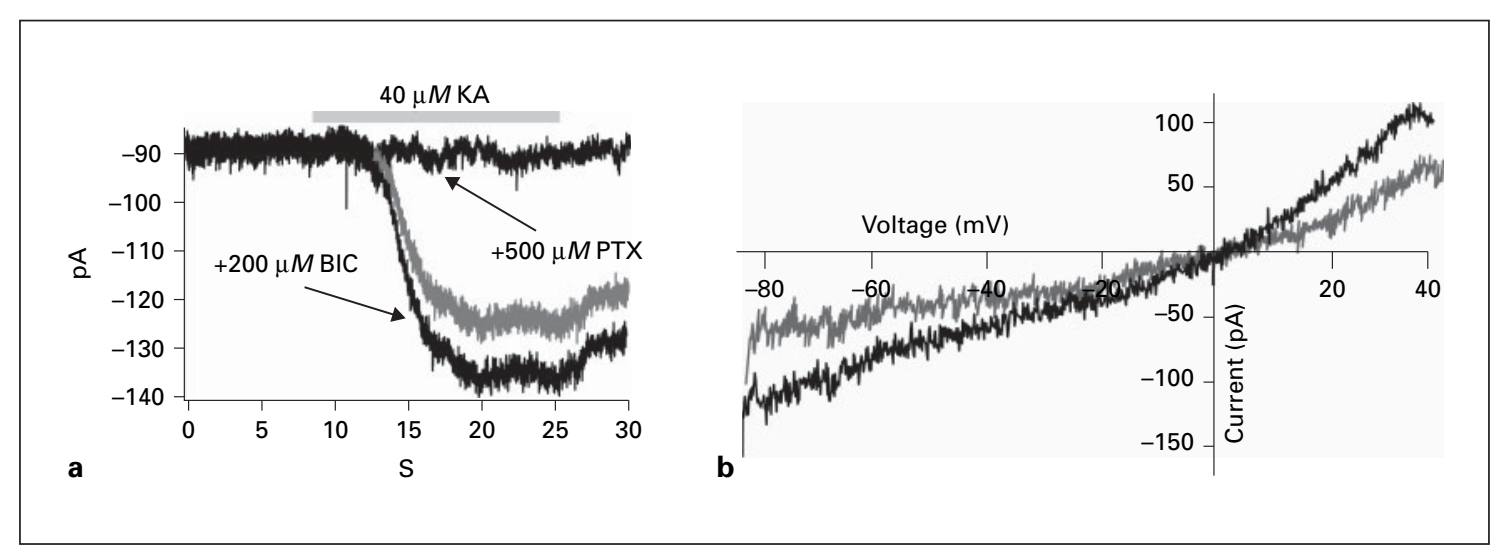

Fig. 7. Inward currents are induced from cones by kainate application in retinal slice preparations. a An inward current with a 5-second delay was recorded in a cone when $40 \mu M$ kainate (KA) was added into the bath medium. The experiment was performed in the presence of a background light $\left(10.1 \mu \mathrm{W} / \mathrm{mm}^{2}\right)$. The GABA current induced by kainate perfusion (grey trace) was potentiated by BIC $(200 \mu M)$ added into the bath medium, but completely suppressed by picrotoxin (PTX). The cone was hold at $-60 \mathrm{mV}$. b I-V relationships of the kainate $(40 \mu M)$-induced current responses of the cone shown in (a) recorded in the absence and presence of $200 \mu \mathrm{M}$ BIC. Both curves yielded an $\mathrm{E}_{\text {rev }}$ of about $+5 \mathrm{mV}$, close to the $\mathrm{E}_{\mathrm{Cl}}$ under our experimental conditions $\left(5.1 \mathrm{mV}, 25^{\circ} \mathrm{C}\right)$. These curves were achieved by subtracting the control currents to the voltage ramp ranging from -80 to $+40 \mathrm{mV}$ in normal Ringer's from the data obtained in the presence of $40 \mu M$ kainate (grey curve) and $40 \mu M$ $\mathrm{KA}+200 \mu M \mathrm{BIC}$ (dark curve). Similar results were obtained in 5 other cones. termined the reversal potentials for the kainate-induced current and the BIC-potentiated kainate current (fig. 7b). The I-V relationships determined by voltage ramps for these currents indicated that the reversal potentials were about $+5 \mathrm{mV}$ in both cases, very close to the $\mathrm{E}_{\mathrm{Cl}}(5.1 \mathrm{mV}$, $25^{\circ} \mathrm{C}$ ) under our experimental conditions. Similar results were obtained in 5 other cones.

\section{Discussion}

\section{Ionotropic GABA Receptor of Novel Pharmacology at}

\section{Bullfrog Cone Terminals}

Immunocytochemical studies have demonstrated labeling of $\mathrm{GABA}_{\mathrm{A}}$ and $\mathrm{GABA}_{\mathrm{C}}$ receptor subunit isoforms at the cone axon terminal in several species [17, 20-24]. Electrophysiologically, it was first reported that GABAinduced chloride currents from isolated turtle cones were completely blocked by BIC, suggesting involvement of $\mathrm{GABA}_{\mathrm{A}}$ receptors [26]. In salamander retinal slice preparations, $\mathrm{Wu}$ [36] showed that a light step elicited a depolarization in cones, while the outer segments of these cells were truncated off. The depolarization was only partially suppressed by BIC, suggesting the possible existence of $\mathrm{GABA}_{\mathrm{C}}$ receptors at the cone terminal. Using a photoreceptor-glia co-culture model, it was further found that
GABA responses of adult porcine cones consisted of two distinct components, a BIC-sensitive one and an I4AAsensitive one [25]. This is also the case for mouse cones in situ [14].

In the present work, we studied ionotropic GABA receptors at the bullfrog cone terminal. Responses of bullfrog cones to focal application of GABA to their terminals were indeed mediated by chloride channels. $\mathrm{EC}_{50}$ for GABA of the receptor is much lower than that for $\mathrm{GABA}_{\mathrm{A}}$ receptors $(10-100 \mu M)$, but close to that for GABA $_{C}$ receptors $(1-5 \mu M)$. The responses mediated by this receptor were sustained without desensitization and they were activated by CACA and suppressed by I4AA, but not modulated by pentobarbital $(200 \mu M, \mathrm{n}=12$, data not shown). These pharmacological properties are reminiscent of those, typical of traditional $\mathrm{GABA}_{\mathrm{C}}$ receptors. But the responses mediated by this receptor to GABA, muscimol and CACA are all potentiated by BIC, which is widely used to distinguish $\mathrm{GABA}_{\mathrm{C}}$ receptors from $\mathrm{GABA}_{\mathrm{A}}$ receptors. To our best knowledge, this peculiar phenomenon is without precedent. It was of interest that muscimol-induced currents were all potentiated by BIC in a range of $1-1,000 \mu M$ (fig. 4b), whereas CACA-induced currents were potentiated by BIC at lower concentrations $(<10 \mu M)$, but suppressed at higher concentrations $(>30 \mu M)$ (fig. $5 \mathrm{~b}, \mathrm{c})$. These observations suggest a 
possibility that there might be two populations of receptors. While this possibility could not be ruled out, we tend to think, according to the occlusion experiments shown in figure $5 \mathrm{~d}$, that there is only a single type of GABA receptors with novel pharmacology at the cone terminal.

The mechanisms underlying the BIC-induced potentiation remain to be further explored. A working model is proposed here for the explanation of the phenomenon. The Hill coefficient is known to be related to the number of co-operative site or binding site of a receptor [37, 38]. The Hill coefficients of this GABA receptor were all close to 1 for GABA-, muscimol-induced and BIC-potentiated currents, but they were larger than 1 for CACA-induced and gabazine-, I4AA-suppressed currents. While the traditional $\mathrm{GABA}_{\mathrm{A}}$ receptor is thought to have two binding sites for GABA [12, 32, 33], our results raised a possibility that GABA and muscimol may share an identical binding site on the receptor whereas either antagonists (e.g. gabazine and I4AA) or agonist CACA may each possess two binding sites. While BIC binds to the same site for GABA on traditional $\mathrm{GABA}_{\mathrm{A}}$ receptors [39], BIC may be able to bind to the antagonist site, in addition to the GABA site in this unique GABA receptor. When BIC binds to the GABA site, it may synergetically act on this receptor with GABA, thus potentiating the GABA current. The fast component of GABA currents appearing in the presence of BIC (fig. 2b) may be due to an allosteric activation mechanism, as occurs in the recombinant $\mathrm{GABA}_{\mathrm{A}}$ receptors containing a mutated $\beta_{2}$ subunit [40]. On the other hand, BICs binding to the antagonist site would suppress the GABA current. When the concentration of BIC is raised to a rather high level, so that the suppression effect of BIC overwhelms the potentiation effect, the GABA current would then be suppressed by BIC. It is a real puzzle that $\mathrm{BIC}$ and gabazine differentially act on this GABA receptor, while these two $\mathrm{GABA}_{\mathrm{A}}$ receptor antagonists are thought to bind to identical sites [41]. A possible explanation for the different actions may be that they differentially modulate the site(s) that is(are) involved in direct gating of the channel, since they are shown to work as allosteric inhibitors of channel opening of the $\mathrm{GABA}_{\mathrm{A}}$ receptor and induce conformational changes of the receptor [40]. In this regard, it is noted that gabazine was reported to block $\mathrm{GABA}_{\mathrm{C}}$ responses in perch horizontal cells [42].

It should be also noted that the CACA-induced currents always possess rather fast activation and deactivation, implying that CACA may bind to and dissociate from this receptor with kinetics faster, as compared to other agonists (e.g. GABA, muscimol), and have a differ- ent gating mechanism. Actually, the fast deactivation of the CACA currents somewhat bears a resemblance to the characteristic kinetics of perch- $\rho 2 \mathrm{~A}$ homo-oligomeric GABA receptors expressed in Xenopus oocytes [43].

\section{Novel Pharmacology of the Ionotropic GABA}

Receptor May Be Related to a Unique Subunit

Composition and/or an Assembly with an Unrevealed New Subunit

Recent evidence suggests that there is a great diversity of ionotropic GABA receptors, which are different in kinetics, affinity for agonists and antagonists [2], and the existence of ionotropic GABA receptors with unique pharmacological properties has been demonstrated. In the chick embryo retina GABA receptors expressed on amacrine and ganglion cells can be blocked by BIC and positively modulated by barbiturates, but they are insensitive to picrotoxin [44]. In cat retina heterogeneous types of $\mathrm{GABA}_{\mathrm{A}}$ receptors are segregated into different zones: those in the distal retina are sensitive only to BIC whereas those in the proximal retina are sensitive to both BIC and picrotoxin [45]. In lobster central neurons (olfactory projection neurons and thoracic neurons) ionotropic GABA receptors appear to differ in pharmacology from vertebrate $\mathrm{GABA}_{\mathrm{A}}$ and $\mathrm{GABA}_{\mathrm{C}}$ receptors in that they are insensitive to $\mathrm{BIC}$ and gabazine, and exhibit other unique agonist potency sequences [46]. This diversity may be ascribed to the composition of ionotropic GABA receptors. These receptors are pentameric complexes of subunits, known as $\alpha, \beta, \gamma, \delta, \varepsilon, \pi$, and $\rho$ subunits, and a new $\theta$ subunit was recently added to this list [47]. Most of the subunits have several members. Different subunit assemblies provide the basis for the functional diversity of ionotropic GABA receptors. It is known, for instance, that different $\alpha, \beta$ subunits underlie distinct affinities of GABA binding and $\gamma$ subunits confer the sensitivity to benzodiazepines on the receptor [2]. It was recently found that $\mathrm{GABA}_{\mathrm{A}}$ receptor subunits $\gamma_{2}$ and $\delta$ confer unique kinetic properties on recombinant GABA receptor currents in mouse fibroblasts [48]. Therefore, the novel pharmacology of the ionotropic GABA receptor expressed at the bullfrog cone terminals should be resulted from a unique subunit composition, different from that of traditional $\mathrm{GABA}_{\mathrm{A}}$ or $\mathrm{GABA}_{\mathrm{C}}$ receptors. Indeed, co-assembly of $\mathrm{GABA}_{\mathrm{A}}$ and $\rho$ subunit has been shown to contribute probably to the molecular organization of $\mathrm{GABA}_{\mathrm{C}}$ receptors in the retina [49-51]. It is also highly possible that an unrevealed new subunit may be assembled. Even though we are not sure whether ionotropic GABA receptors of similar pharmacology may be found in other central neu- 
rons or other species, it is definitely of interest to determine what kind of subunit composition may be responsible for the BIC-induced potentiation and to uncover the site(s) BIC and gabazine may differentially act on using recombinant GABA receptors containing different subunits.

\section{Acknowledgements}

This work was supported by grants from the National Program of Basic Research sponsored by the Ministry of Science and Technology of China (2006CB5008), the National Science Foundation of China $(90408003,30570593)$, the Shanghai Commission of Science and Technology (C010607) and the '211' Project sponsored by the Ministry of Education of China.

\section{References}

1 Yang XL: Characterization of receptors for glutamate and GABA in retinal neurons. Prog Neurobiol 2004; 73:127-150.

2 Chebib M, Johnston GA: The 'ABC' of GABA receptors: a brief review. Clin Exp Pharmaco Physiol 1999;26:937-940.

-3 Bowery NG, Price GW, Hudson AL, Hill DR, Wilkin GP, Turnbull MJ: GABA receptor multiplicity: visualization of different receptor types in the mammalian CNS. Neuropharmacology 1984;23:219-231.

-4 Kerr DI, Ong J: GABAB receptors. Pharmacol Ther 1995:67:187-246.

-5 Marshall FH, White J, Main M, Green A, Wise $\mathrm{A}: \mathrm{GABA}_{\mathrm{B}}$ receptors function as heterodimers. Biochem Soc Trans 1999;27:530-535.

-6 Johnston GA: GABA receptor pharmacology. Pharmacol Ther 1996;69:173-198.

7 Kusama T, Spivak CE, Whiting P, Dawson VL, Schaeffer JC, Uhl GR: Pharmacology of GABA rho 1 and GABA alpha/beta receptors expressed in Xenopus oocytes and COS cells. Br J Pharmacol 1993;109:200-206.

$\checkmark 8$ Du JL, Yang XL: Subcellular localization and complements of $\mathrm{GABA}_{\mathrm{A}}$ and $\mathrm{GABA}_{\mathrm{C}}$ receptors on bullfrog retinal bipolar cells. J Neurophysiol 2000;84:666-676.

-9 Johnston GA: Medicinal chemistry and molecular pharmacology of $\mathrm{GABA}_{\mathrm{C}}$ receptors. Curr Top Med Chem 2002;2:903-913.

10 Johnston GA: $\mathrm{GABA}_{\mathrm{C}}$ receptors. Prog Brain Res 1994;100:61-65.

-11 Bormann J, Feigenspan A: GABA ${ }_{C}$ receptors. Trends Neurosci 199518:515-519.

12 Feigenspan A, Bormann J: Differential pharmacology of $\mathrm{GABA}_{\mathrm{A}}$ and $\mathrm{GABA}_{\mathrm{C}}$ receptors on rat retinal bipolar cells. Eur J Pharmacol 1994; 288:97-104.

13 Lukasiewicz PD: GABA ${ }_{\mathrm{C}}$ receptors in the vertebrate retina. Mol Neurobiol 1996;12:181194.

14 Pattnaik B, Jellali A, Sahel J, Dreyfus H, Picaud S: $\mathrm{GABA}_{\mathrm{C}}$ receptors are localized with microtubule-associated protein $1 \mathrm{~B}$ in mammalian cone photoreceptors. J Neurosci 2000;20: 6789-6796.

15 Chang Y, Weiss DS: Channel opening locks agonist onto the $\mathrm{GABA}_{\mathrm{C}}$ receptor. Nat Neurosci 1999;2:219-225.

16 Qian H, Dowling JE, Ripps H: A single amino acid in the second transmembrane domain of GABA rho subunits is a determinant of the response kinetics of $\mathrm{GABA}_{\mathrm{C}}$ receptors. J Neurobiol 1999;40:67-76.
7 Yazulla S, Studholme KM, Vitorica J, de Blas AL: Immunocytochemical localization of $\mathrm{GABA}_{\mathrm{A}}$ receptors in goldfish and chicken retinas. J Comp Neurol 1989;280:15-26.

18 Mitchell CK, Huang B, Redburn-Johnson DA: $\mathrm{GABA}_{\mathrm{A}}$ receptor immunoreactivity is transiently expressed in the developing outer retina. Vis Neurosci 1999;16:1083-1088.

19 Vardi N, Masarachia P, Sterling P: Immunoreactivity to $\mathrm{GABA}_{\mathrm{A}}$ receptor in the outer Plexiform layer of the cat retina. J Comp Neurol 1992;320:394-397.

20 Mitchell CK, Redburn DA: GABA and GABAA receptors are maximally expressed in association with cone synaptogenesis in neonatal rabbit retina. Brain Res Dev Brain Res 1996; 95:63-71.

21 Wang H, Standifer KM, Sherry DM: GABA receptor binding and localization in the tiger salamander retina. Vis Neurosci 2000;17:1121.

22 Zhang J, De Blas AL, Miralles CP, Yang CY: Localization of $\mathrm{GABA}_{\mathrm{A}}$ receptor subunits alpha 1 , alpha 3 , beta 1 , beta $2 / 3$, gamma 1 , and gamma 2 in the salamander retina. J Comp Neurol 2003;459:440-453.

23 Greferath U, Grunert U, Muller F, Wassle H: Localization of $\mathrm{GABA}_{\mathrm{A}}$ receptors in the rabbit retina. Cell Tissue Res 1994;276:295-307.

24 Yazulla S, Studholme KM: Light adaptation affects synaptic vesicle density but not the distribution of $\mathrm{GABA}_{\mathrm{A}}$ receptors in goldfish photoreceptor terminals. Microsc Res Tech 1997; 36:43-56.

25 Picaud S, Pattnaik B, Hicks D, Forster V, Fontaine V, Sahel J, Dreyfus $\mathrm{H}: \mathrm{GABA}_{\mathrm{A}}$ and $\mathrm{GABA}_{\mathrm{C}}$ receptors in adult porcine cones: evidence from a photoreceptor-glia co-culture model. J Physiol 1998;513:33-42.

26 Kaneko A, Tachibana M: Effects of gammaaminobutyric acid on isolated cone photoreceptors of the turtle retina. J Physiol 1986;373: 443-461.

27 Wu SM: Feedback connections and operation of the outer plexiform layer of the retina. Curr Opin Neurobiol 1992;2:462-468.

28 Liu J, Zhao JW, Du JL, Yang XL: Functional $\mathrm{GABA}_{\mathrm{B}}$ receptors are expressed at the cone photoreceptor terminals in bullfrog retina. Neuroscience 2005; 132:103-113.

29 Li GL, Li P, Yang XL: Melatonin modulates gamma-aminobutyric acid(A) receptor-mediated currents on isolated carp retinal neurons, Neurosci Lett 2001;301:49-53.
30 Yang CY, Lukasiewicz P, Maguire G, Werblin FS, Yazulla S: Amacrine cells in the tiger salamander retina: morphology, physiology, and neurotransmitter identification. J Comp Neurol 1991;312:19-32.

$31 \mathrm{Lu}$ T, Shen Y, Yang XL: Desensitization of AMPA receptors on horizontal cells isolated from crucian carp retina. Neurosci Res 1998; 31:123-135.

32 Bormann J, Clapham DE: Gamma-aminobutyric acid receptor channels in adrenal chromaffin cells: a patch-clamp study. Proc Natl Acad Sci USA 1985;82:2168-2172.

33 Sakmann B, Hamill OP, Bormann J: Patchclamp measurements of elementary chloride currents activated by the putative inhibitory transmitter GABA and glycine in mammalian spinal neurons. J Neural Transm 1983;18(suppl):83-95.

34 Yang XL, Wu SM: Coexistence and function of glutamate receptor subtypes in the horizontal cells of the tiger salamander retina. Vis Neurosci 1991;7:377-382.

35 Massey SC, Miller RF: Excitatory amino acid receptors of rod- and cone-driven horizontal cells in the rabbit retin. J Neurophysiol 1987; 57:645-659.

36 Wu SM: Input-output relations of the feedback synapse between horizontal cells and cones in the tiger salamander retina. J Neurophysiol 1991;65:1197-1206.

37 Ricard J, Noat G: Kinetic co-operativity of monomeric mnemonical enzymes. The significance of the kinetic Hill coefficient. Eur J Biochem 1985; 152:557-564.

38 Yifrach O: Hill coefficient for estimating the magnitude of cooperativity in gating transitions of voltage-dependent ion channels. Biophys J 2004;87:822-830.

39 Korpi ER, Grunder G, Luddens H: Drug interactions at $\mathrm{GABA}_{\mathrm{A}}$ receptors. Prog Neurobiol 2002;67:113-159.

-40 Ueno S, Bracamontes J, Zorumski C, Weiss DS, Steinbach JH: Bicuculline and gabazine are allosteric inhibitors of channel opening of the $\mathrm{GABA}_{\mathrm{A}}$ receptor. J Neurosci 1997; 17:625634.

41 Rognan D, Boulanger T, Hoffmann R, Vercauteren DP, Andre JM, Durant F, Wermuth CG: Structure and molecular modeling of $\mathrm{GABA}_{\mathrm{A}}$ receptor antagonists. J Med Chem 1992;35: 1969-1977. 
42 Qian H, Dowling JE: Pharmacology of novel GABA receptors found on rod horizontal cells of the white perch retina. J Neurosci 1994;14: 4299-4307.

43 Qian H, Dowling JE, Ripps H: Molecular and pharmacological properties of GABA-rho subunits from white perch retina. J Neurobiol 1998;37:305-320.

-44 Shen DW, Higgs MH, Salvay D, Olney JW, Lukasiewicz PD, Romano C: Morphological and electrophysiological evidence for an ionotropic GABA receptor of novel pharmacology. J Neurophysiol 2002;87:250-256.
45 Frumkes TE, Nelson R, Pflug R: Functional role of GABA in cat retina. II. Effects of GABA A $_{A}$ antagonists. Vis Neurosci 1995;12: 651-661.

46 Zhainazarov AB, Wachowiak M, Boettcher A, Elenes S, Ache BW: Ionotropic GABA receptor from lobster olfactory projection neurons. J Neurophysiol 1997; 77:2235-2251.

47 Bonnert TP, McKernan RM, Farrar S, le Bourdelles B, Heavens RP, Smith DW, Hewson L, Rigby MR, Sirinathsinghji DJ, Brown N, Wafford KA, Whiting PJ: Theta, a novel gammaaminobutyric acid type A receptor subunit. Proc Natl Acad Sci USA 1999;96:9891-9896.

48 Haas KF, Macdonald RL: GABA receptor subunit gamma2 and delta subtypes confer unique kinetic properties on recombinant $\mathrm{GABA}_{\mathrm{A}}$ receptor currents in mouse fibroblasts. J Physiol 1999;514:27-45.
49 Qian H, Ripps H: Response kinetics and pharmacological properties of heteromeric receptors formed by coassembly of GABA rho- and gamma 2-subunits. Proc R Soc Lond [B] 1999; 266:2419-2425.

50 Pan ZH, Zhang D, Zhang X, Lipton SA: Evidence for coassembly of mutant $\mathrm{GABA}_{C}$ rho1 with $\mathrm{GABA}_{\mathrm{A}}$ gamma2S, glycine alpha1 and glycine alpha 2 receptor subunits in vitro. Eur J Neurosci 2000;12:3137-3145.

51 Qian H, Pan Y: Co-assembly of GABA rho subunits with the $\mathrm{GABA}_{\mathrm{A}}$ receptor gamma(2) subunit cloned from white perch retina. Brain Res Mol Brain Res 2002;103:62-70. 